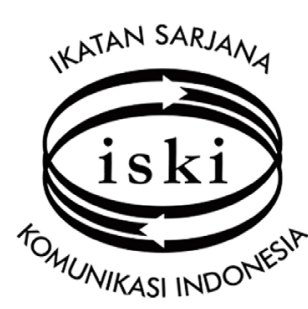

Jurnal Komunikasi. 01 (2016) 58-63

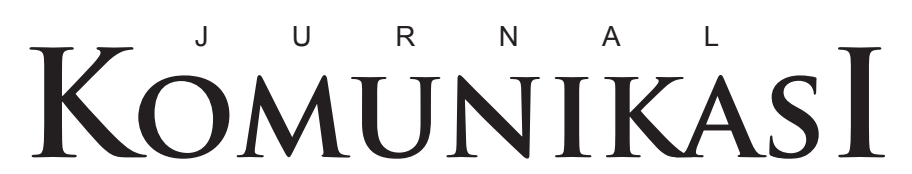

e-ISSN: ---- ---- ---

p-ISSN: ---- ---- ---

IKATAN SARJANA KOMUNIKASI INDONESIA

\title{
TELEPON GENGGAM DAN PERUBAHAN SOSIAL Studi Kasus Dampak Negatif Media Komunikasi dan Informasi Bagi Anak-Anak di Kelurahan Bobosan Purwokerto Kabupaten Banyumas
}

\author{
S. Bekti Istiyanto \\ Ilmu Komunikasi Fisip Universitas Jenderal Soedirman
}

\begin{abstract}
Abstrak:
Perkembangan teknologi komunikasi dewasa ini membawa banyak perubahan sosial. Tidak hanya perubahan pola pikir dalam menyikapi sesuatu, namun juga berdampak pada perubahan perilaku secara sosial. Perubahan yang terjadi ternyata tidak selamanya positif karena di sisi lain juga membawa efek negatif kepada penggunanya. Kondisi ini terutama terjadi untuk anak-anak dan remaja yang kurang mampu memfilter dampak negatif penggunaan media komunikasi terbaru dibandingkan dengan segala kemudahan akses informasi yang dapat mereka serap dan manfaatkan. Penelitian ini bertujuan untuk menggambarkan kaitan antara penggunaan teknologi komunikasi telepon genggam dengan perubahan sosial bagi anak-anak usia sekolah dasar dan sekolah menengah pertama di Kelurahan Bobosan Purwokerto Kabupaten Banyumas. Penelitian ini menggunakan pendekatan kualitatif deskriptif dengan wawancara dan observasi sebagai teknik pengumpulan datanya. Informan dalam penelitian ini adalah anak-anak usia sekolah dasar dan sekolah menengah pertama dan para orang tua yang memiliki anak-anak yang menggunakan media komunikasi. Hasil penelitian menunjukkan bahwa terjadi perubahan sosial bagi anakanak yang menggunakan telepon genggam dalam hal cara berkomunikasi sosial, pola pikir dan perubahan sikap atas informasi yang mereka akses. Kemudahan akses informasi ini juga mempunyai akibat yang negatif dalam penggunaan waktu bermain dengan teman seusianya yang menjadi lebih terbatas dan pengaruh buruk isi media yang merusak seperti pornografi dan seksualitas.
\end{abstract}

Kata kunci: perkembangan teknologi, perubahan, telepon genggam, akses, dampak negatif

\section{LATAR BELAKANG}

Di era informasi seperti saat ini, perkembangan teknologi komunikasi dan informasi seolah-olah telah menjadi sebuah kebutuhan primer setiap keluarga. Hampir di setiap rumah baik dikota bahkan sampai ke desa-desa selalu menghadirkan berbagai bentuk hasil karya teknologi tersebut sebagai bagian kelengkapan bagi penghuni rumahnya. Hasil karya teknologi komunikasi dan informasi menjadi "orang asing" yang akibat globalisasi telah menjadi begitu leluasa hadir di tengah-tengah keluarga, mengajari penggunanya apa saja setiap saat, mengubah pola hidup, mendatangkan kebiasaan-kebiasaan baru, bahkan dikatakan bahwa kebutuhan akan teknologi tersebut sebagai bentuk orang hipnotis canggih yang mampu mengubah perilaku dan cara mereka berkomunikasi dengan orang lain.

Salah satu bentuk kehadiran teknologi komunikasi dan informasi di dunia dewasa ini adalah alat komunikasi portable berupa telepon seluler atau telepon genggam (handphone). Dengan kemudahan akses informasi siapa pun dapat menerima dan mengirim informasi apapun dengan cepat bagi siapa saja dan tidak terbatas oleh usia. Kehadirannya telah membawa dampak yang sangat besar bagi umat manusia. Dengan sinyal internet yang disediakan beberapa penyedia layanan informasi (provider) semakin terus berkembang dalam hal kecepatan dan jaringannya, membuat siapa pemegang telepon genggam dapat dengan mudah membukanya kapan 
pun dan dimana pun.

Telepon genggam seolah-oleh telah menjadi kebutuhan wajib yang harus dimiliki oleh setiap orang. Ia membawa berbagai kandungan informasi, pesan-pesan yang dalam kecepatan tinggi menyebar ke seluruh pelosok dunia. Menjadi berbagai alat bagi berbagai kelompok untuk menyampaikan berbagai pesan untuk bermacam kalangan masyarakat. Orang sekarang ini bahkan dapat berkomunikasi tanpa harus bertatap muka secara langsung dalam suatu tempat tertentu menggunakan media ini. Berbahai kemudahan lainnya juga berkembang dengan seiring berkembangnya spesifikasi kelebihan fitur-fitur yang dimiliki dan ditampilkan oleh setiap telepon genggam masing-masing.

Akan tetapi ada hal lain yang muncul akibat berkembangnya telepon genggam ini. Muncul efek bagi pribadi dan efek secara sosial yang cenderung negatif ketika penggunaannya tidaklah sesuai dengan kebutuhan pemakainya. Secara tidak langsung hal ini akan mengakibatkan perubahan polapola kehidupan rutinitas manusia dan interaksi di dalam lingkungan masyarakat dimana mereka tinggal.

Salah satu dampak negatif telepon genggam justru muncul bagi anak-anak usia sekolah dasar dan menengah pertama ketika kebebasan penggunaan telepon genggam ini diberlakukan tanpa penyaring dari para orang tuanya secara memadai. Minimal ada dua dampak negatif yang cenderung dominan dari penggunaan telepon genggam tersebut bagi mereka, yaitu tersedianya game online secara bebas akses dan munculnya pornografi secara massif. Ketersediaan game online merupakan satu fitur dalam telepon genggam yang menjadikan anak-anak usia sekolah begitu 'membutuhkannya', sehingga secara jelas dan kasat mata efek ini dapat dibuktikan dengan mudah. Berbeda dengan efek pornografi yang ada dunia maya lebih cenderung tertutup dan tidak diumbar dengan bebas oleh anak-anak usia sekolah meski ternyata penyebarannya juga semakin meluas dan mudah ditemui bahkan di lingkup sekolah sekalipun.

Atas dasar latar belakang di atas menjadikan permasalahan tentang kaitan perkembangan teknologi komunikasi dan informasi bagi anak-anak usia sekolah sangat penting untuk dilakukan. Telepon genggam sekarang ini bukan lagi menjadi barang yang asing bagi anak-anak bahkan bagi mereka yang tinggal di kota-kota kecil seperti
Purwokerto sekalipun, seperti Kelurahan Bobosan Kecamatan Purwokerto Utara yang dapat dikategorikan oleh penulis sebagai desa menengah, yaitu desa pertengahan dimana pola hidup masyarakatnya tinggal di antara desa tradisional dan desa perkotaan.

Permasalahan. Permasalahan yang dapat diurai dalam tulisan ini adalah "Bagaimana kaitan dampak negatif media komunikasi dan informasi bagi anakanak di Kelurahan Bobosan Kecamatan Purwokerto Utara Kabupaten Banyumas?”

\section{TINJUAN PUSTAKA}

Beberapa penelitian yang telah dipublikasikan terkait tema dampak telepon genggam bagi anakanak ini antara lain: penelitian yang dilakukan oleh Rian Baruna Permana Putra (2014) yang menjelaskan handphone memiliki dampak negatif seperti mengganggu perkembangan anak, efek radiasi, rawan melakukan tindak kejahatan, berpotensi mempengaruhi perubahan sikap dan perilaku siswa, dan pemborosan. Salah satu bukti penjelasnya menganggap penyimpanan foto atau video porno sebagai salah satu bentuk penyimpangan yang dikategorikan sebagai sebuah bentuk kenakalan remaja.

Penelitian lain telah dilakukan oleh Mia Purwanti (2010) dengan metode kuantitatif ini menghasilkan kesimpulan seperti adanya hubungan yang sangat kuat antara pengaruh penggunaan handphone terhadap kepribadian dan prestasi siswa. Kemudian siswa akan lebih berprestasi bila dapat meminimalkan waktu dalam penggunaan handphone yang tidak penting, dan mengalihkannya dengan cara mengisi hal-hal positif.

Penelitian yang dilakukan oleh Mulya Haryani R, Mudjiran, Yarmis Syukur (2012) menjelaskan betapa mudahnya siswa mengakses film/video porno yang memungkinkan mereka secara bebas menonton sehingga menimbulkan kecenderungan bagi remaja/ siswa untuk menonton film porno secara berulangulang. Hal ini berdampakpada sulitnya berkonsetrasi dalam belajar, akibatnya hasil belajar siswa rendah. Penelitian yang bertujuan untuk mengungkap bagaimana dampak pornografi terhadap perilaku seksual remaja/siswa inimenyimpulkan bahwa pornografi sangat berdampak terhadap perilaku seksual siswa dan guru pembimbing belum optimal (rendah) dalam mengupayakan pencegahan agar siswa tidak mengakses pornografi. 


\section{PERKEMBANGAN TEKNOLOGI KOMUNIKASI DAN INFORMASI BAGI PERUBAHAN SOSIAL}

Perkembangan teknologi komunikasi diawali dengan berkembangnya media massa cetak, radio, film, televisi, komputer, sistem TV kabel, satelit, direct brodcasting system, telepromter, teletex dan sebagainya. Kesemuanya tersebut dengan mudah telah diadopsi dan masuk ke seluruh penjuru dunia, bahkan William Paisley (dalam Rogers, 1986) menyimpulkan bahwa "Technological change has placed communication on front of lines of a social revolution". Dissayanake (dalam Rogers, 1986) mengartikan revolusi sosial ini dengan istilah revolusi komunikasi yaitu peledakan teknologi komunikasi seperti terlihat melalui meningkatnya penggunaan satelit, mikro-prosesor komputer, dan pelayanan radio tahap tinggi, serta perubahan yang terjadi sebagai konsekuensi yang ditempa oleh bidang sosial, ekonomi, politik, kultur, dan gaya hidup manusia. Sedangkan Schramm (1988) mengingatkan bahwa perkembangan yang dinamakan revolusi komunikasi ada sebagainya itu merupakan bagian dari serangkaian perubahan yang telah berlangsung dalam sejarah kehidupan manusia selama ini (dalam Nasution, 2004: 2).

Mahluk hidup yang normal seperti manusia selalu membutuhkan informasi untuk menjaga kelangsungan hidupnya, dan untuk mendapatkan informasi tersebut manusia perlu berkomunikasi dengan manusia lain. Kemajuan teknologi komunikasi dan informasi yang sedemikian pesatnya saat ini menjadikan informasi sangat berlimpah dan seolah-olah tidak mempunyai batas lagi, dan penggunanyalah yang tinggal memilah dan memilih mana informasi yang dikategorikan sebagai sampah dan mana informasi yang dibutuhkan untuk kehidupan mereka.

Kemajuan teknologi dewasa ini telah menawarkan bungkahan sumber-sumber atau resources informasi dan komunikasi yang amat luas yang pernah dipunyai oleh umat manusia. Menurut Nasution (2004: 3) dunia sedang berubah, bentuk masyarakat yang seperti apa yang kelak muncul sebagai hasil dari gerak perubahan ini diramalkan oleh berbagai ahli seperti yang disebutkan oleh Wizard (1982) di antaranya George Lichtein yang menyebut masa yang baru ini sebagai post-bourgeois; Ralph Dahrendorf menggunakan istilah Postcapitalism; Amitai Etzioni menjuluki post-modern; sedangkan Kenneth Boulding memakai istilah postcivilized, namun dalam hal popularitas istilah yang diajukan sosiolog Harvard, Daniel Bell, menyebutnya dengan istilah masyarakat post-industrial.

Inti dari perkembangan teknologi komunikasi dan informasi seperti yang diungkap oleh para ahli di atas adalah terjadinya perubahan sosial yang menimpa manusia sebagai pengguna aktif perkembangan teknologi tersebut. Perubahan tersebut dapat bernilai positif ketika teknologi digunakan sesuai dibutuhkan, sebaliknya ketika semua perkembangan teknologi digunakan tidak sesuai kebutuhan dan bahkan cnderung memberikan pengaruh buruk maka dapat dikatakan itu sebagai dampak negatif perubahan.

Sedikit untuk memahami perubahan sosial, dapat dikatakan bahwa sebenarnya setiap masyarakat selama hidupnya pasti mengalami perubahanperubahan. Perubahan masyarakat dapat mengenai nilai-nilai sosial, lembaga kemasyarakatan, polapola prilaku organisasi, lapisan-lapisan dalam masyarakat, interaksi sosial dan sebagainya. Perubahan-perubahan yang terjadi pada masyarakat dunia dewasa ini merupakan gejala yang normal. Pengaruhnya bisa menjalar dengan cepat ke bagianbagian dunia lain berkat adanya perkembangan teknologi komunikasi dan informasi modern yang sangat cepat. Penemuan-penemuan baru di bidang teknologi yang terjadi di suatu tempat dengan cepat dapat diketahui oleh masyarakat lain yang berada jauh dari tempat tersebut.

Soekanto (2010), mengatakan bahwa kecenderungan terjadinya perubahan-perubahan sosial merupakan gejala wajar yang timbul dari pergaulan hidup manusia. Bahkan ada pendapat lain bahwa perubahan sosial terjadi karena adanya perubahan dalam unsur-unsur yang mempertahankan keseimbangan seperti; perubahan dalam unsur-unsur geografis, biologis, ekonomis atau kebudayaan. Perubahan sosial menurut Kingsley Davis (dalam Istiyanto dan Bahri, 2005) mengemukakan bahwa perubahan sosial merupakan bagian dari perubahan kebudayaan. Intinya perubahan sosial umumnya merupakan lingkaran kejadian-kejadian.

Salah satu sumber perubahan sosial adalah adanya penemuan baru yaitu suatu proses perubahan sosial dan kebudayaan yang besar, tetapi yang terjadi dalam jangka waktu yang tidak terlalu lama, yang sering kita namakan inovasi. Proses tersebut meliputi suatu penemuan baru, jalannya 
unsur kebudayaan baru yang tersebar ke lain bagian masyarakat. Penemuan-penemuan baru seperti telepon genggam dapat menjadi penyebab terjadinya perubahan-perubahan yang dapat dibedakan dalam pengertian discovery dan invention. Discovery adalah penemuan unsur kebudayaan yang baru, baik berupa alat, ataupun berupa gagasan yang diciptakan oleh seorang individu dan serangkaian ciptaan para individu. Discovery baru menjadi invention kalau masyarakat telah mengakui, menerima serta menerapkan penemuan baru itu.

\section{METODE PENELITIAN}

Tulisan ini didasari oleh hasil penelitian yang dilakukan di Kelurahan Bobosan Kecamatan Purwokerto Utara Kabupaten Banyumas. Penelitian ini sendiri menggunakan pendekatan kualitatif kualitatif deskriptif. Metode ini dipilih karena dapat menggambarkan, menjelaskan dan membangun hubungan dari kategori-kategori dan data yang ditemukan (Moleong, 2000).

Subjek penelitian ini adalah masyarakat yang tinggal di Kelurahan Bobosan Kecamatan Purwokerto Utara Kabupaten Banyumas. Sedangkan objek penelitian ini adalah kaitan penggunaan teknologi komunikasi dan informasi dengan dampak negatif yang menerpa anak-anak usia sekolah. Dalam proses pengumpulan data di lapangan, penulis menjadikan anak-anak usia sekolah dasar dan menengah pertama serta orang tua yang memperbolehkan anaknya menggunakan telepon genggam. Mereka dipilih karena dianggap memahami permasalahan penelitian sebagai informan.

Untuk mengumpulan data dalam penelitian ini menggunakan participant observe atau pengamatan berperan serta, wawancara mendalam, dan telaah dokumen. Untuk menguji kemantapan dan keabsahan data yang telah berhasil dikumpulkan, penelitian ini menggunakan teknik triangulasi data. Menurut Patton, triangulasi data adalah usaha membandingkan dan mengecek balik derajat kepercayaan suatu informasi yang diperoleh melalui waktu dan alat yang berbeda dalam metode kualitatif (dalam Moleong, 2000: 330). Dalam penelitian ini, peneliti menggunakan triangulasi sumber dengan cara membandingkan data hasil pengamatan dengan hasil wawancara dan membandingkan hasil wawancara dengan isi suatu dokumen yang terkait.

\section{PEMBAHASAN}

Segala perkembangan teknologi tentulah membawa pengaruh kepada penggunanya, baik sedikit atau banyak tergantung sejauh mana pengaruh tersebut dapat dirasakan. Demikian juga dengan perkembangan telepon genggam. Sepuluh atau dua puluh tahun yang lalu penggunaan telepon genggam masih sangat terbatas hanya kepada lapisan masyarakat tertentu. Akan tetapi dewasa ini hampir semua lapisan masyarakat menggunakannya. Tidak ditentukan oleh batasan usia, seolah-oleh telepon genggam merupakan keharusan untuk dimiliki. Hal ini juga berlaku kepada pengguna mereka di kalangan anak-anak usia sekolah.

Telepon genggam dapat dipastikan mempunyai efek kepada penggunanya seperti yang disampaikan oleh Mulya Haryani R, Mudjiran, Yarmis Syukur (2012). Efek yang dimunculkan dapat dimungkinkan terjadinya perubahan dalam beberapa hal seperti perubahan pandangan, sikap, pendapat, tingkah laku, prestise, prestasi, harga diri, dan perubahan lain yang terjadi pada penggunanya. Karena itu, bersikap waspada terhadap efek yang ditimbulkan oleh media ini merupakan suatu langkah yang hatihati dan bijaksana. Pendapat ini disampaikan oleh Andre, informan dari orang tua yang mengijinkan anak-anaknya memegang telepon genggam di usia sekolah dasar.

Tidak semua informasi yang ada adalah benar dan dibutuhkan oleh anak-anak. Apalagi bila tidak ada pengendalian dan penyaring dari orang tua. Senada dengan bapak Andre, ibu Mimin informan dari orang tua juga menyampaikan pendapat senada tentang perlunya perhatian dan pengendalian saat anak-anaknya bermain telepon genggam. Ibu Mimin mengungkapkan bahwa dia dan suaminya pernah kecolongan karena pada suatu saat mendapati riwayat mesin pencari dalam telepon genggam android anaknya pernah membuka sebuah situs porno. Bahkan di file video yang tersimpan dalam memori telepon genggan anaknya tersebut terdapat juga video berdurasi pendek tentang adegan berhubungan antara laki-laki dan perempuan.

Kekagetan dan rasa shock seketika muncul dan kemudian menanyai anaknya kenapa bisa ada riwayat pencarian gambar porno dan tersimpannya sebuah video seronok dalam telepon genggamnya. Saat itulah ibu Mimin dan suami cenderung berhatihati dan lebih memberikan perhatian kepada anakanaknya ketika mereka bermain telepon genggam 
android terutama ketika mereka bermain bersama teman-temannya.

Tema pornografi memang sudah sangat mewabah dan seolah-olah telah menjadi bumbu yang harus ada seiring perkembangan teknologi komunikasi dan informasi. Dengan berbekal telepon genggam canggih dan adanya pulsa untuk internet yang cukup atau jaringan wifi yang kini menjamur di Kelurahan Bobosan menjadikan setiap orang sangat mudah mengakses situs-situs pornografi dan seksualitas ini. Informan dari anak-anak usia sekolah dasar, Azel, mengungkapkan bahwa temanteman mainnya banyak yang pernah melihat atau menyimpan gambar atau adegan pornografi di telepon genggam yang mereka punyai. Dengan berbekal fasilitas pengiriman yang semakin canggih dalam telepon genggam seperti bluetooth maka proses pengiriman file tidak akan berlangsung lama. Tinggal klik maka akan langsung terkirim dan tersimpan.

Informan dari anak-anak usia sekolah dasar kelas enam, Syamsu, mengungkapkan bahwa melihat gambar atau video yang tergolong unsur pornografi dan seks buat dirinya sudah berlangsung dalam waktu yang cukup lama dan bukan menjadi sesuatu hal yang baru baginya. Syamsu ini mengungkapkan bahwa dirinya tahu pertama kali dari telepon genggam milik orang tuanya yang tidak tahu saat ia memegang dan memainkannya. Kemudian ia menceritakan ke teman-temannya bahkan kemudian ada yang meminta dan ia mengirimkannya via bluetooth. Ketika ia berulang tahun dan mendapatkan hadiah dari permintaannya saat kelas empat sekolah dasar berupa telepon genggam maka ia menjadi lebih leluasa memainkan dan atau membuka situs-situs pornografi selain main game online kesukaanya.

Agak berbeda dengan Syamsu, informan dari anak usia sekolah menengah pertama yaitu Rizki, mengungkapkan bahwa dirinya tahu akan situssitus porno saat kelas lima sekolah dasar. Pada awalnya hanya mencoba-coba atau iseng untuk mencari menggunakan mesin google dalam telepon genggamnya. Berbekal panduan satu kata semisal telanjang atau ML (making love) yang dia coba maka kemudian terbuka beberapa situs pornografi yang ia lihat atau bahkan download ke dalam memori telepon genggamnya. Tetapi saat sudah sekolah SMP frekuensi membuka situs pornografi atau menyimpan gambar dan video sudah jarang ia lakukan. Alasan yang Rizki sampaikan adalah tugas di sekolahnya sudah sangat menyita jadi kalau sempat buka teepon genggam biasanya hanya main game atau nulis status di media sosial semacam facebook atau ngobrol di forum chatting line atau BBM.

Persoalan seks atau pornografi memang bukan barang yang baru, karena seks termasuk tema-tema yang sensitif karenanya seks selalu mengundang perhatian. Menurut Schiffman dan Kanuk (2006) seks terus menjadi tema yang selalu meningkat karena seks merupakan hal yang paling mendasar dalam motif manusia. Di Amerika sendiri, 35\% iklan yang ditayangkan di televisi bertemakan tentang seks (Soley dan Reid dalam Istiaynto, 2002). Padahal ternyata pemirsa televisi di Amerika diterpa 1500 pesan melalui televisi yang mereka konsumsi.

Kondisi di Amerika sebenarnya sudah menjadi hal yang jamak terjadi di Indonesia. Hampir semua media massa juga ikut berperan serta menyumbang informasi tentang seks dan pornografi dalam kebanyakan program-programnya (Istiyanto, 2002). Terlebih lagi dengan kehadiran teknologi komunikasi dan informasi semacam internet dan telepon genggam yang sangat pribadi dan lebih individualis. Kemudahan akses dan terbukanya banyak informasi mengenai seks dan pornografi menjadikannya sebagai sesuatu yang umum dan ada di sekitar kita, termasuk kelurahan Bobosan di kota kecil seperti Purwokerto.

Pornografi dan seks memang bukanlah barang baru di negara kita, akan tetapi pengakses informasi di kalangan anak-anak baik usia sekolah dasar maupun sekolah menengah pertama atau atas tetaplah sebuah kondisi yang wajar dan sudah seharusnya begitu. Sebelum perkembangan teknologi internet pembicaraan tentang seks dan pornografi masih dianggap sangat tabu. Ini berbeda dengan situasi sekarang ini. Sangat terasa adanya perubahan pandangan dan sikap perilaku atas tema pornografi dan seks di masyarakat. Perubahan atas cara pandang dan sikap ini masuk dalam kategori perubahan sosial seperti disampaikan oleh Soekanto (2010) bahwa perubahan sosial merupakan gejala wajar yang timbul akibat dari pergaulan hidup manusia.

Perubahan sosial lain yang terjadi bagi anakanak usia sekolah di Kelurahan Bobosan Purwokerto adalah dalam hal cara berkomunikasi sosial, pola pikir dan perubahan sikap atas informasi yang 
mereka akses. Bagi informan dari orang tua seperti bu Nana dan pak Rofiq, anak-anak sekarang lebih cenderung bersikap semaunya, individualis dan acuh dengan dunia sekitarnya. Fokus perhatian dan konsentrasi lebih kuat tertuju kepada gadget yang mereka mainkan dibanding harus berinteraksi dengan teman-teman seusianya.

Rutinitas aktivitas yang cenderung sama setiap harinya menjadikan anak-anak juga semakin sedikit waktu luang untuk berkumpul atau bermain di areal terbuka. Mereka membandingkan masa dulu ketika belum memegang telepon genggam dengan sekarang dimana anak-anak sudah kecanduan bermain gadget yang mereka punyai. Efek secara langsung yang terlihat menurut informan adalah anak-anak lebih menyukai duduk bermain game online sepulang sekolah dibandingkan harus bermain ke luar rumah.

Perubahan sikap dan cara berkomunikasi juga terjadi di Kelurahan Bobosan. Hal ini diungkapkan oleh pak Andre dan pak Ali yang secara langsung terasa seperti 'menyalahkan' efek bermain telepon genggam. Mereka menjelaskan ketika anak-anak dipanggil maka mereka akan cenderung menyelesaikan permainannya terlebih dahulu dibandingkan segera memenuhi panggilan orang tuanya. Meskipun demikian pak Rofiq menjelaskan adanya nilai manfaat ketika anaknya memegang telepon genggam yaitu anaknya menjadi sering bertanya kepadanya ketika merasa ada yang belum diketahuinya.

\section{KESIMPULAN}

Perubahan sosial dalam masyarakat pastilah terjadi. Perkembangan teknologi komunikasi dan informasi hanya semakin mempercepat terjadinya perubahan tersebut. Bagi anak-anak usia sekolah dasar dan menengah pertama meskipun tidak disadari perubahan sosial dalam beberapa hal telah terjadi. Baik perubahan dalam hal cara berkomunikasi secara sosial, pola pikir dan perubahan sikap atas informasi yang mereka akses. Kemudahan akses informasi juga membawa dampak-dampak berikutnya termasuk persoalan pornografi dan seksualitas. Kondisi tersebut ada dan terjadi di Kelurahan Bobosan Purwokerto. Anakanak usia sekolah merasa biasa dan jamak ketika harus melihat, membuka, menyimpan dan membagi file berupa gambar dan video berbau pornografi dan seks kepada teman-teman sebaya mereka.

\section{DAFTAR PUSTAKA}

Istiyanto, S. Bekti. 2002. Wanita dalam Gambaran Iklan Televisi Kita. Purwokerto: Jurnal Komunikasi Acta Diurna Vol 1 No 1 November 2002.

Istiyanto, S. Bekti dan Bahri, Asep Syaiful. 2005. Teori Komunikasi untuk Perubahan Sosial. Bogor: Artikel IPB

Mia Purwanti. 2010. http://miapurwanti.blogspot. com/2010/12/pengaruh - penggunaanhandphone-terhadap.html diakses tanggal 23 Oktober 2014

Moleoeng, Lexy J. 2000. Metode Penelitian Kualitatif. Bandung: Remaja Rosdakarya.

Mulya Haryani R, Mudjiran, dan Yarmis Syukur. 2012. Dampak Pornografi Terhadap Perilaku Siswa Dan Upaya Guru Pembimbing Untuk Mengatasinya. http://ejournal.unp.ac.id/index. php/konselor. Jurnal Ilmiah Konseling. Volume 1 Nomor 1 Januari 2012. Diakses tanggal 23 Oktober 2014

Nasution, Zulkarimein. 2004. Perkembangan Teknologi Komunikasi. Jakarta: Universitas Terbuka

Schiffman, Leon dan Kanuk, Leslie Lazar. 2006. Perilaku Konsumen. Jakarta: Penerbit : Indeks Puri Media Kembangan

Schramm, Wilbur. 1988. Television Relasional. Singapura: Asian Mass Communication Research and Information Culture.

Soekanto, Soerjono. 2010. Sosiologi Suatu Pengantar. Jakarta: Rajawali Press

Rian Baruna Permana Putra.https://megameydhiant. wordpress.com/tag/dampak-penggunaanhandphone-bagi-pelajar-sma-di-kec-bangsri/ diakses tanggal 23 Oktober 2014 